\title{
Association of Single Nucleotide Polymorphism in Melanocortin Receptor Gene with Egg Production Traits in Lohmann Brown Chickens
}

\author{
Karim EL-SABROUT 's Sarah AGGAG ${ }^{2}$ \\ ${ }^{1}$ Department of Poultry Production, Faculty of Agriculture (El-Shatby), University of Alexandria, Alexandria, EGYPT \\ ${ }^{2}$ Department of Genetics, Faculty of Agriculture (El-Shatby), University of Alexandria, Alexandria, EGYPT
}

Article Code: KVFD-2017-18474 Received: 20.07.2017 Accepted: 25.10.2017 Published Online: 30.10.2017

Citation of This Article

El-Sabrout K, Aggag S: Association of single nucleotide polymorphism in melanocortin receptor gene with egg production traits in Lohmann Brown chickens. Kafkas Univ Vet Fak Derg, 24 (1): 145-148, 2018. DOI: 10.9775/kvfd.2017.18474

\begin{abstract}
Melanocortin receptor (MC4R) plays an important role in central melanocortin system and regulation of feed intake in birds. In this study the melanocortin gene (MC4R) was proposed as a candidate gene for egg production traits (yield and weight) in Lohmann Brown hens. DNA from blood samples was extracted to amplify the MC4R gene and the purified PCR products were sequenced. Alignment of sequence data from each group revealed that there is a variation detected in MC4R-1 at nucleotide 22 (T-G) (sense mutation) for high egg weight. Hens with the $A B$ genotype produced significantly higher egg weight compared to hens with the AA genotype. There was no significant effect of this mutation on egg yield. The detected mutation and the analysis of egg production means revealed a significant association between MC4R polymorphism and egg weight. The MC4R-SNP could be considered as a useful marker in chicken selection especially for egg weight.
\end{abstract}

Keywords: Lohmann Brown, MC4R, Egg weight, SNP, Sense mutation

\section{Lohmann Kahverengi Tavuklarda Melanocortin Reseptörü Geninde Tek Nükleotid Polimorfizmi İle Yumurta Verim Özellikleri Arasındaki İlişki}

\begin{abstract}
Özet
Melanocortin reseptörü (MC4R) merkezi melanocortin sisteminde ve kuşlarda yem tüketiminin düzenlenmesinde önemli rol oynar. Bu çalışmada melanocortin geninin (MC4R) Lohmann Kahverengi tavuklarda yumurta verim özellikleri (sayı ve kilo) üzerine etkili bir gen olabileceği düşünülmüştür. MC4R genini amplifiye etmek amacıyla kan örneklerinden DNA ekstrakte edildi ve PCR ürünlerinin sekanslaması yapıldı. Her bir grupta sekans verisinin dizilimi MC4R-1'in nükleotid 22'sinde (T-G) (Sense mutasyon) yüksek yumurta ağırlığı için varyasyon bulunduğunu ortaya koydu. AB genotipine sahip tavuklar AA genotipine sahip tavuklar ile karşılaştırıldığında istatistiki olarak daha yüksek yumurta ağırlığına sahiptiler. Bu mutasyonun yumurta sayısı üzerine bir etkisi bulunmamaktaydı. Tespit edilen mutasyon ve ortalama yumurta üretimi analizi MC4R polimorfizmi ile yumurta ağırlığı arasında anlamlı bir ilgi bulunduğunu gösterdi. MC4R-SNP özellikle yumurta ağırlığı bakımından önemli bir belirteç olarak kullanılabilir.
\end{abstract}

Anahtar sözcükler: Lohmann Kahverengi, MC4R, Yumurta ağırlığı, SNP, Sense mutasyon

\section{INTRODUCTION}

Understanding the associations between genotype and phenotype is very important for faster improvement in animal breeding with potential economic benefits. Results inferred from molecular genetic studies play an important role in breeding value prediction systems and in the construction of commercial lines and populations. In the $20^{\text {th }}$ century, strong selection of production traits started when commercial breeds were selected for egg and meat production ${ }^{[1]}$. Selection programs based on productive traits have been of major importance to the poultry industry. Amie-Marini et al ${ }^{\left[{ }^{[2]}\right.}$ reported that single nucleotide polymorphism (SNP) is an effective method to detect nucleotide sequence mutation in amplified DNA. The investigation strategy for a specific favorable SNP involves a novel and lengthy process of the identification of the DNA molecular marker for a major effect gene. Holsinger and Weir ${ }^{[3]}$ revealed the importance of discovery a large number of SNPs in the genomes from several species that has enabled exploration of genome-wide signatures in selection via an assessment of variation in marker allele frequencies

\section{8 iletişim (Correspondence)}

留 +201008984822

kareem.badr@alexu.edu.eg 
among these populations. Genes associated with productive traits have been identified using single nucleotide polymorphisms of many candidate genes ${ }^{[4,5]}$. It is recognized that the egg production traits of chickens are controlled by a complicated multiple genes ${ }^{[6]}$.

Melanocortin 4 receptor (MC4R) is a protein expressed in the hypothalamus in humans and it has been found to be involved in feed intake, the regulation of metabolism and body weight ${ }^{[7]}$. Mutations of the MC4R gene were associated with the appetite and growth in many animal species ${ }^{[8]}$. According to the results of El-Sabrout ${ }^{[9]}$ on rabbit, MC4R gene has many important behavioral and growth functions. Moreover, the mutations of MC4R gene have been found association with carcass quality in cattle ${ }^{[10]}$, and broiler chickens ${ }^{[11]}$.

Few researches have been published to improve the effect of MC4R mutations on egg production traits in chickens. Therefore, the present study was carried out to investigate the association between MC4R gene and the egg production traits (yield and weight) in Lohmann Brown chickens.

\section{MATERIAL and METHODS}

\section{Animal, Housing and Feeding Management}

This experiment was carried out on 200 Lohmann Brown hens (11 months of age). Hens were divided into two groups according to their egg weight (120 hens for control egg weight ( $A A$ avg. $57.7 \mathrm{~g}$ ), 70 hens for high egg weight $(A B$ avg. $60.4 \mathrm{~g}$ ) and 10 hens for low egg weight (BB avg. $55.1 \mathrm{~g})$ ). Birds were housed in single cages with an intensive system and were offered ad libitum access to fed commercial pelleted diet (18\% protein and $2800 \mathrm{Kcal} / \mathrm{kg}$ ). The study was approved by Alexandria University Animal Ethics Committee (2016).

\section{Molecular Analysis}

DNA was extracted from whole blood by taking random blood samples (20 samples per group) from the wing vein in centrifuge tubes containing EDTA as anticoagulant using DNA isolation kit (Zymo ${ }^{\circledR}$ Research, USA) following the manufacturer's protocol and stored at $-20^{\circ} \mathrm{C}$ until used. Two different primers from MC4R gene: MC4R-1 (500 bp) and MC4R-2 (492 bp) ${ }^{[12]}$ were investigate from Biosearch Technologies (USA) to generate PCR profiles from DNA samples (Table 1). The total PCR reaction volume was 25

\begin{tabular}{|c|c|}
\hline Primer Code & Nucleotide Sequence $\left(5^{\prime}-3^{\prime}\right)$ \\
\hline MC4R-1 & $\begin{array}{l}\text { F 5'-CAACCCCAGTTACCAGCACT-3' } \\
\text { R 5'-GCATTGCTGTGCAGTCCATA-3' }\end{array}$ \\
\hline MC4R-2 & $\begin{array}{l}\text { F 5'-CCATTGCAGTGGACAGGTATT-3' } \\
\text { R 5'-TCCGGAGTGCATAAATGAGA-3' }\end{array}$ \\
\hline
\end{tabular}

$\mu \mathrm{L}$, included $3 \mu \mathrm{L}$ of genomic DNA of each group, $1 \mu \mathrm{L}$ of each primer, $15 \mu \mathrm{L}$ of $2 \times$ Thermo Multiplex PCR Master Mix and $6 \mu \mathrm{L}$ of RNase-free water. PCR program was performed using a thermal cycler (Thermo ${ }^{\circledR}$ Scientific Corporation, EU) included three main steps: initial denaturation at $95^{\circ} \mathrm{C}$ for $5 \mathrm{~min}$, followed by 35 cycles, denaturation at $95^{\circ} \mathrm{C}$ for $30 \mathrm{sec}$; annealing at $45^{\circ} \mathrm{C}$ for $30 \mathrm{sec}$ and lasted by extension at $72^{\circ} \mathrm{C}$ for $1 \mathrm{~min}$ then an extension cycle at $72^{\circ} \mathrm{C}$ for $8 \mathrm{~min}$. Amplicones were separated on 1.5\% agarose gel, stained with Ethidium Bromide and visualized under UV Transilluminator. GelAnalyzer application ${ }^{[13]}$ was used to analysis the determined DNA bands on the agarose gel. The amplified DNA fragments of growth genes were digested with MSP1. The RFLP was carried out on PCR product according to Zhou et al. ${ }^{[14]}$. The purified DNA was sequenced using the automated sequencer by Macrogene Company (South Korea). Sequence analysis and alignment were carried out using the CodonCode Aligner software (http:// www.codoncode.com/aligner).

\section{Egg Production Traits}

Data of egg yield (\%) and egg weight (g) ( $n=50$ samples per group) were recorded daily during the experiment period (6 months). Egg weight of all eggs was determined with digital balance $(\mathrm{g})$.

\section{Statistical Analysis}

Statistics of means differences in egg and weight production between the two groups were determined by ANOVA followed by Duncan's multiple range test using SPSS ${ }^{[15]}$. The association between the genotypes of MC4R gene and the egg production traits were analyzed by the means and standard errors method as applied in the General Linear Model (GLM) procedure of SPSS ${ }^{[15]}$ according to the following statistical model:

$Y_{i j m}=\mu+G_{i}+E Y_{j}+e_{i j m}$

Where $Y$ is the dependent variable (egg weight), $\mu$ is the overall mean of observations, $G$ is the fixed genotype effect, EY (egg yield) is the covariate, and e is the residual error.

\section{RESULTS}

All primers were amplified and yielded distinct polymorphic PCR profiles at molecular weight ranged from 210 to $370 \mathrm{bp}$. RFLP analysis of PCR product using MSP1 did not produce restriction fragments. The results of MC4R-1 electrophoresis showed three genotypes ( $A A, A B$ and $B B$ ) with frequencies of $0.60,0.35$ and 0.05 , respectively (Table 2). The frequency of allele $A$ was 0.78 while the frequency of allele $B$ was 0.22 . It means that allele $A$ was dominant in Lohmann Brown hens. The purified PCR products were sequenced in those had the highest and lowest egg weight. Alignment of sequence data of 15 samples from 


\begin{tabular}{|c|c|c|c|c|c|}
\hline \multicolumn{6}{|c|}{ Table 2. Genotype and allele frequencies of MC4R-1 in Lohmann Brown } \\
\hline $\begin{array}{c}\text { Number of } \\
\text { Hens }\end{array}$ & \multicolumn{3}{|c|}{ Genotype Frequency (n) } & \multicolumn{2}{c|}{ Allele Frequency } \\
\cline { 2 - 6 } & AA & AB & BB & A & B \\
\hline 200 & $0.60(120)$ & $0.35(70)$ & $0.05(10)$ & 0.78 & 0.22 \\
\hline
\end{tabular}

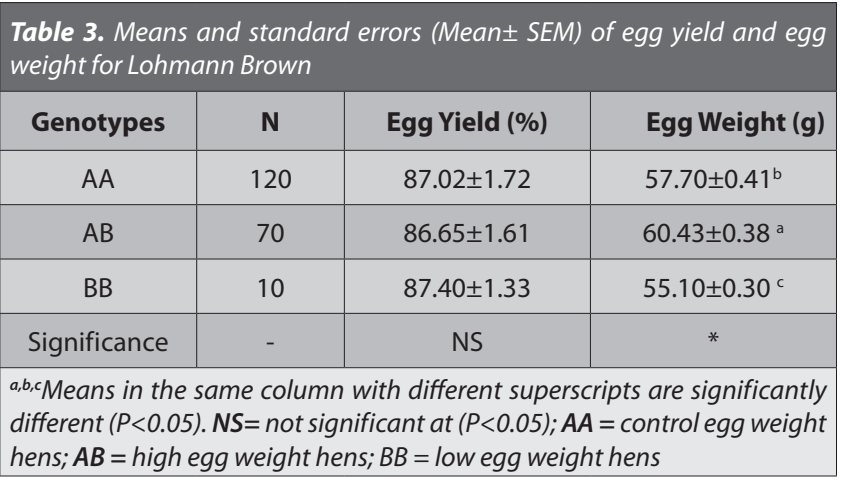

\begin{tabular}{|c|c|c|c|c|}
\hline \multirow{2}{*}{ SNPs } & \multirow{2}{*}{ Trait } & \multicolumn{2}{|c|}{ Genotypes } & \multirow{2}{*}{ P-value } \\
\hline & & AA & $A B$ & \\
\hline MC4R-1 & Egg weight (g) & $57.70 \pm 0.41^{b}$ & $60.43 \pm 0.38^{a}$ & 0.03 \\
\hline
\end{tabular}

Values are presented by the means and standard errors (Mean \pm SEM); $a, b$ Means in the same row with different superscripts are significantly different $(P<0.05)$

each group revealed that there is a mutation detected in MC4R-1 at nucleotide 22 (T-G) (sense mutation) for high egg weight, while there was no variation detected in MC4R-2. Means and standard errors (Mean \pm SEM) of egg yield and egg weight shown in Table 3. AB genotype had significantly $(P<0.05)$ higher egg weight compared with $A A$. On the other hand, there was no significant difference detected between the two groups in egg yield. MC4R gene showed significant $(\mathrm{P}<0.05)$ association with egg weight in Lohmann strain (Table 4). The results of SNP polymorphisms demonstrate the possibility to detect association between egg weight in Lohmann chickens and the efficiency of the used primers to predict through the genetic specificity using the single nucleotide polymorphism of MC4R.

\section{DISCUSSION}

Many previous studies were interested to investigate the relationship between the melanocortin-4 receptor gene (MC4R) and the body weight of animal. To determine whether there was an association of MC4R polymorphism with egg production traits in chickens, this study was carried to test two parts of MC4R gene (MC4R-1, MC4R-2) as candidate gene for Lohmann Brown hens (commercial layers strain). The frequency of heterozygous genotype $(A B)$ has higher egg weight compared to homozygous (AA) and (BB) genotypes. Also, one sense mutation was identified in high egg weight group (AB). Therefore, it may be assumed that the MC4R-1 gene affected egg weight by regulating of appetite of hens. Analyses of MC4R SNPs and egg weight records showed significant association of MC4R genotypes with egg weight (Table 4).

Davies et al. ${ }^{[9]}$ reported that sense mutation can change the gene expression, which in turn a different protein with different characterizes is created as a result of amino acids change. This protein may lose its function or become activated or exhibit a new function. It is possible that the variation happened in amino acids due to the MC4R mutations causes a significant change of the MC4R function. Amino acids change may also affect the biosynthesis of other nutrients. It can stimulate the feed intake, metabolism and growth of egg, which in turn affect the egg weight. This finding is in agreement with ElSabrout and Aggag [17], who found that MC4R plays an area responsible for controlling feed intake behavior, which in turn affect the body weight.

In addition, the effect of MC4R in chicken's egg weight suggests it may be an important genetic marker for the production-related traits. The hens within hetero-zygous genotype $(A B)$ at the MC4R gene loci had superior egg production traits. This finding is useful to get commercial egg production chickens with superior production traits. Therefore, this study aims also to enhance selection efficiency on hen productive performance. The use of marker-assisted selection can augmented the efficient genetic improvement in these quantitative traits ${ }^{[18]}$. Moreover, MC4R SNPs located at candidate genes for economic traits allow prediction of the genetic merit of individuals and combined with guarantee consumer protection.

According to the results of this study, there is a significant association between MC4R gene polymorphism and egg weight in Lohmann Brown chickens. The results of single nucleotide polymorphism demonstrate the efficiency of used associated genes to predict through the genetic specificity. The results are also effective in chicken selection for high egg weight without affecting the egg yield. MC4R1 SNP was potential useful DNA marker for selecting excellent individuals in marker-assist selection (MAS) breeding in relation to egg production traits in chickens. Further studies through expanded and different sampling with more details under various molecular levels will be required to provide clearer explanations.

\section{ACKNOWLedgement}

Our special thanks to the director of Abdel Rahman farm and his great team work - for their kind assistance and support during this study.

\section{REFERENCES}

1. Burt DW: Chicken genome: Current status and future opportunities. 
Genome Res, 15, 1692-1698, 2005. DOI: 10.1101/gr.4141805

2. Amie-Marini AB, Aslinda $K$, Mohd-Hifzan $R$, Muhd-Faisal $A B$, Musaddin K: Haelll-RFLP Polymorphism of growth hormone gene in Savanna and Kalahari goats. Mal J Anim Sci, 15, 13-19, 2012.

3. Holsinger KE, Weir BS: Genetics in geographically structured populations: defining, estimating and interpreting FST. Nat Rev Genet, 10, 639-650, 2009. DOI: 10.1038/nrg2611

4. Zhang GW, Gao L, Chen SY, Zhao XB, Tian YF, Wang X, Deng XS, Lai SJ: Single nucleotide polymorphisms in the FTO gene and their association with growth and meat quality traits in rabbits. Gene, 527, 553-557, 2013. DOI: 10.1016/j.gene.2013.06.024

5. Wu ZL, Chen SY, Jia XB, Lai SJ: Association of a synonymous mutation of the PGAM2 gene and growth traits in rabbits. Czech J Anim Sci, 60, 139-144, 2015. DOI: 10.17221/8079-CJAS

6. Gu X, Feng C, Ma L, Song C: Genome-wide association study of body weight in chicken F2 resource population. PLoS One, 6, e21872. 2011. DOI: 10.1371/journal.pone.0021872

7. Chun-Yu L, Hui L: Association of MC4R gene polymorphisms with growth and body composition traits in chicken. Asian-Aust J Anim Sci, 19, 763-768, 2006. DOI: 10.5713/ajas.2006.763

8. Sinha PS, Schioth HB, Tatro JB: Roles of the melanocortin-4 receptor in antipyretic and hyperthermic actions of centrally administered alpha-MSH. Brain Res, 1001 (1-2): 150-158, 2004. DOI: 10.1016/j.brainres.2003.12.007

9. El-Sabrout K: Associations between single-nucleotide polymorphisms of melanocortin gene and sexual desire behavior in rabbit (Oryctolagus cuniculus). J Vet Behav, 19, 69-71, 2017. DOI: 10.1016/j.jveb.2017.02.005

10. Zhang CL, Wang YH, Chen H, Lan XY, Lei CZ, Fang XT: Association between variants in the 50-untranslated region of the bovine MC4R gene and two growth traits in Nanyang cattle. Mol Biol Rep, 36, 1839-1843,

\section{DOI: 10.1007/s11033-008-9388-z}

11. Wang $Y$, Su $Y$, Jiang XS, Liu YP: Study on association of single nucleotide polymorphism of MC3R and MC4R genes with carcass and meat quality traits in chicken. J Poult Sci, 46, 180-187, 2009. DOI: 10.2141/jpsa.46.180

12. Fontanesi L, Scotti E, Cisarova K, Di Battista P, Dall'Olio S, Fornasini D, Frabetti A: A missense mutation in the rabbit melanocortin 4 receptor (MC4R) gene is associated with finishing weight in a meat rabbit line. Anim Biotechnol 24, 268-277, 2013. DOI: 10.1080/10495398.2013.781034

13. Gelanalyzer: Gel Analyzer Software. Ver. 3.1 for windows, 2010.

14. Zhou GL, Jin HG, Liu C, Guo SL, Zhu Q Wu YH: Association of genetic polymorphism in GH gene with milk production traits in Beijing Holstein cows. J Biosci, 30, 595-598, 2005. DOI: 10.1007/BF02703558

15. SPSS, Statistical Package for the Social Sciences: SPSS User's Guide: Statistics, Version 20.0 for Windows, Institute, Inc., Cary, NC, USA, 2011.

16. Davies H1, Bignell GR, Cox C, Stephens P, Edkins S, Clegg S, Teague J, Woffendin H, Garnett MJ, Bottomley W, Davis N, Dicks E, Ewing R, Floyd Y, Gray K, Hall S, Hawes R, Hughes J, Kosmidou V, Menzies A, Mould C, Parker A, Stevens C, Watt S, Hooper S, Wilson R, Jayatilake H, Gusterson BA, Cooper C, Shipley J, Hargrave D, Pritchard-Jones K, Maitland N, Chenevix-Trench G, Riggins GJ, Bigner DD, Palmieri G, Cossu A, Flanagan A, Nicholson A, Ho JW, Leung SY, Yuen ST, Weber BL, Seigler HF, Darrow TL, Paterson H, Marais R, Marshall CJ, Wooster R, Stratton MR, Futreal PA: Mutations of the BRAF gene in human cancer. Nature, 417, 949-954, 2002. DOI: 10.1038/nature00766

17. El-Sabrout K, Aggag SA: Associations between single nucleotide polymor-phisms in multiple candidate genes and body weight in rabbits. Vet World, 10, 136-139, 2017. DOI: 10.14202/vetworld.2017.136-139

18. Rothschild MF, Plastow G: Advances in pig genomics and industry applications. Ag Biotech Net, 1, 1-8, 1999. 